

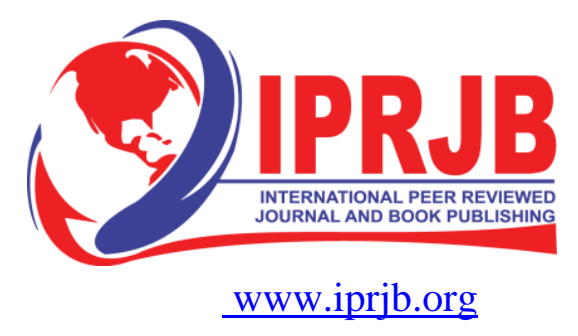

\title{
INTEREST RATE, MONEY SUPPLY AND GROWTH OF MORTGAGE FINANCING AMONG COMMERCIAL BANKS IN KENYA \\ ${ }^{1 *}$ Chanzu Newton Luyali \\ 1* Post Graduate Student, Jomo Kenyatta University of Agriculture and Technology, Kenya \\ *Corresponding Author's Email: newtonchanzuluyali@yahoo.com
}

\author{
${ }^{2}$ Dr. Bichanga Julius M \\ ${ }^{2}$ Lecturer, Jomo Kenyatta University of Agriculture and Technology, Kenya \\ ${ }^{3}$ Dr. Gekara M \\ ${ }^{3}$ Lecturer, the East African University, Kenya
}

\begin{abstract}
Purpose: The purpose of this study was to investigate the effects of interest rate and money supply on the growth of mortgage financing among Commercial banks in Kenya.

Materials and methods: The study adopted a descriptive research design. The population contained 35 loan lending commercial banks over a period between 1985 and 2019. Secondary data was used from desired financial statements available to the public of the singular commercial banks and other posted reports of financial institutions and establishments in conformity with the study. Time-series data were analyzed using STATA version 13 software, regression analysis and model specification tests. The hypothesis was tested using the multiple regression approach a significance level of 0.05 was used.

Results: The study found that interest rate $(\operatorname{coef}=-0.0822, \mathrm{p}=0.007)$ and money supply (coef $=$ $0.548, \mathrm{p}=0.00$ ) have significant effects on the growth of mortgage financing among Kenyan commercial banks.

Unique contribution to theory, practice and policy: Kenya's central bank should put in place mechanisms to guarantee that interest rates and money supply do not have adverse impacts on bank mortgage financing. The government should guarantee currency stability since currency fluctuations may have a negative impact on commercial bank mortgage borrowing. The classical theory is therefore relevant in our research since interest rates impact mortgages when capital demand increases. The quantity theory of money demand also holds that individuals want cash based on the transactions they need.
\end{abstract}

Keywords: Interest Rate, Money Supply, Growth of Mortgage Financing 
International Journal of Finance and Accounting

ISSN 2513-4311X (online)

Vol.6 Issue 2, No.1. pp. 1 - 11, 2021

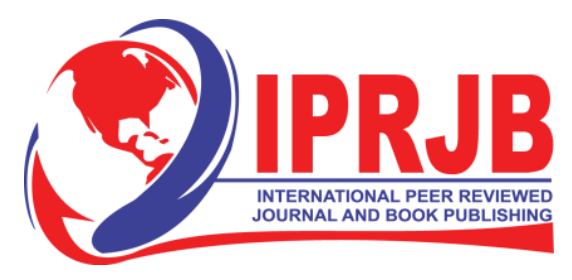

moved in the same direction leading to a slower pace of development and growth in the mortgage sector.

There is a need to address issues surrounding the slow growth of the mortgage sector by making loans available and accessible to a wider range of people (Kariuki, 2017) suggests that. The house financing portfolio has remained low with a value of Ksh. $61.5 \mathrm{~B}$ and less than 15000 mortgage accounts. This is too far below the expectation of over 156000 house units per year. Arvantis (2016) the average amount of mortgage loan stood at Ksh. 6.6 million, both in banks and at the housing finance cooperation. The repayment of this amount will require installments of Ksh. 90,000 monthly for 20 years and above with a fixed rate of $12 \%$.

Central Bank of Kenya, (2012) report revealed factors that slow down the development of mortgage financing. The findings among others reported that the credit risk, high interest rate, disparities in property pricing and long-term access to funds were some of the factors. The report cited immense variance between the short-termed deposits and long-term mortgage loans as a hindrance to growth. Hass Consult Survey (2013) in its survey established that the real estate market is characterized by uncertainties in prices that are set without professional intervention which in turn has an effect on repayment and the value of the credit. Consequently, the mortgage lending institutions set up a high-risk premium rendering the mortgage facility expensive.

\section{Statement of the Problem}

The banking industry is one of the sectors being used to facilitate the realization of vision 2030, to this end, there is a need of ensuring the provision of financial services and investment opportunities that will create an efficient, vibrant and globally competitive financial services environment in Kenya (Central Bank of Kenya, 2017). In Kenya, the growth in mortgage financing has been poor despite Central Banks' interest rate capping. For instance, mortgage accounts holders in $\mathrm{KCB}$ bank which is the leading mortgage lender in Kenya went down to 6496 from 7007 in 2015, a decline of 7.3\%. Housing Finance, the second-largest mortgage provider in the country, also saw a decline in its customers from 5,993 to 5,711 which was $4.7 \%$ lower as compared to the same period. In 2017, mortgage accounts for all the banks reduced from 24,458 in 2016 to 24,085 which was a reduction of $1.5 \%$ in the same period (Central Bank of Kenya, 2017).

Various studies have been conducted in Kenya on mortgage financing. Jumbale (2016) sought to establish the relationship between the prices of houses and real estate financing. Muli (2016) on the other hand studied the relationship between prices of property and mortgage lending in Kenya. Leonard and Owiti (2013), when investigating the determinants of mortgage uptake, found out that the capital market negatively affected mortgage growth. A closely related study by Agao (2014) on the effect of macroeconomic drivers on mortgages within the Kenyan mortgage sector found a significant and negative association between mortgage uptake and inflation rates, and positive relationships with the rate of interest and the level of the money supply. This study, therefore, sought to establish if there are any linkages between the interest rate and money supply on the growth of mortgage financing among commercial banks in Kenya. 


\subsection{Conceptual Framework}

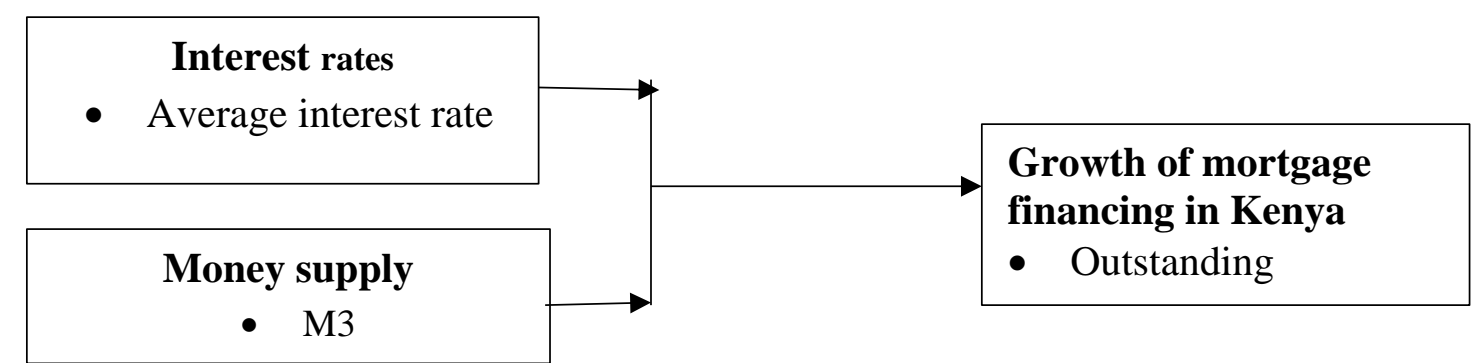

\section{Independent Variables}

Dependent Variable

\section{Figure 1: Conceptual Framework}

\subsection{Empirical Literature Review}

Mixed evidence has been reported by prior studies of the effect of interest rate on banks' profitability, for instance, Rashid and Jabeen (2016) reported a negative effect of interest rate on banks' performance, Yahya, Akhtar, and Tabash (2017) found a positive effect. The high-interest rates in Kenya are among the principal reason why the mortgage market remains underdeveloped. Estate, (2016) concludes that compared to its counter in Sub-Sahara, (South Africa) which has a mortgage debt to GDP ratio of $20 \%$, Kenya stands at a mere $4.5 \%$. (CBK, 2015) also notes that it's significantly smaller compared to that of the US which stood at $70 \%$. The high-interest rate environment is a result of the high inflation prevalent in Kenya which according to (Boamah, 2017) stifles the development of a mortgage market.

Olweny (2011) found that IR volatility has a positive correlation with interest rates that are shortterm in nature. A positive and significant correlation existed between volatility and the rates of interest. Muguchia (2017), sought to find out how, mortgage financing; is influenced by flexible interest rates. A negative and significant relationship was found on the study variables. The study recommended fixed interest rates to be established by the banks so that investors can project and plan the possible interest amount to pay back; hence increasing the uptake for the mortgage.

Karoki (2013) applied a descriptive research approach to find out what diatremes prices of the real estate sector in Kenya. To establish the determinants, a multivariate regression analysis was conducted. On the outcomes; interest rates, GDP and supply of money influenced prices of real estate which were positive and significant. The greatest influence on the dependent was interest rates, followed by GDP and then money supply. Mwangi, (2006) sought to identify the determinants of mortgage finance uptake. The study covered the period from 2001-2005. The independent variables were money supply, liquidity ratio and inter-bank funds rate. The study utilized secondary data from the CBK. The study findings showed that money supply had the greatest effect, explaining $41 \%$ of the variations in mortgage finance uptake. The liquidity ratio and inter-bank funds rate were found to have an insignificant influence on mortgage finance uptake. Income levels in Kenya are both low in absolute terms and also very unevenly distributed. This is a common occurrence in the majority of sub-Saharan Africa and is one of the single most difficult barriers to overcome in building a vibrant mortgage market (World Bank, 2011). 


\subsection{METHODOLOGY}

The study used a descriptive research design. The target population for this study consisted of a census of all the 42 commercial banks licensed by the Central Bank of Kenya (Central Bank of Kenya, 2019). In this study, the accessible population comprised 35 mortgage lending commercial banks (Central Bank of Kenya, 2016). The study utilized data for a period of thirty-five years, covering the period; January 1985 to December 2019. Data on the dependent and independent variables were collected by the use of secondary data, mainly from financial statements between the years 1985-2019 of individual commercial banks in Kenya under study. After data collection, cleansing of the data was done to ensure that it is complete. Times series data analysis was done by the use of STATA version 13 software. Various diagnostic tests were carried out to ascertain the appropriateness of the data for regression analysis. Tests for normality, multicollinearity and heteroscedasticity were conducted.

\subsection{RESULTS}

\subsection{Descriptive Statistics}

\section{Table 1: Descriptive summary statistics}

\begin{tabular}{r|rrrrr} 
Variable & Obs & Mean & Std. Dev. & Min & Max \\
\hline IR & 35 & 18.01714 & 5.228625 & 12.4 & 30.5 \\
M3 & 35 & 2241158 & 383489.7 & 1768900 & 3400000
\end{tabular}

The mean interest rate between 1985 and 2019 was 18.0 with a standard deviation of 5.2. The minimum interest rate was 12.4 and the maximum was 30.5 . The money supply had a mean of 2241.1.6B, a minimum of $1768.9 \mathrm{~B}$ and a maximum of $3400 \mathrm{~B}$.

\subsection{Correlation Analysis}

Correlation analysis statistics were worked out to establish the relationship between the predictor variables and the dependent variable.

\section{Table 2: Correlation matrix}

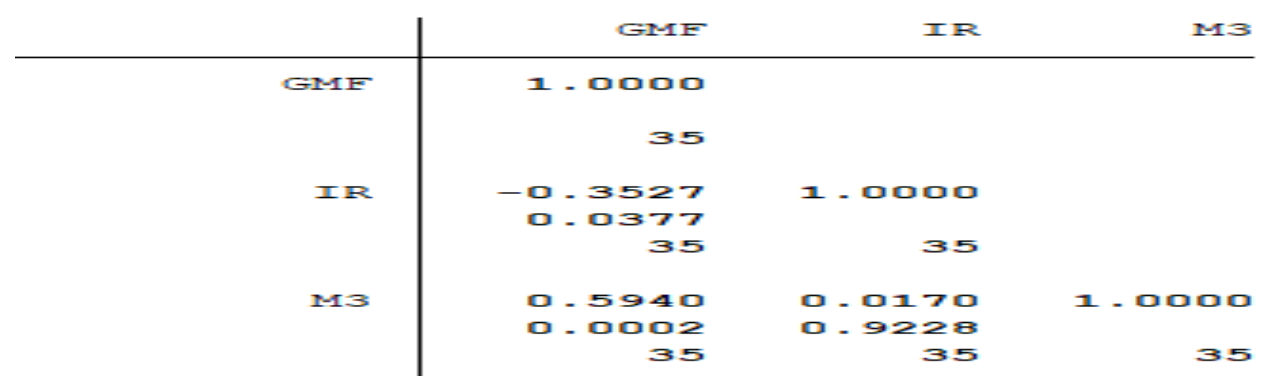

The outputs of the correlation matrix show that interest rate has a significant negative relationship with the growth of mortgage financing. $T(r=-0.3527, p$ value= 0.0377). A significance level of 0.05 was used. The position is supported by the classical theory of interest rate which holds that interest rate determines the demand for capital (Drumond, 2013). 
International Journal of Finance and Accounting

ISSN 2513-4311X (online)

Vol.6 Issue 2, No.1. pp. 1 - 11, 2021

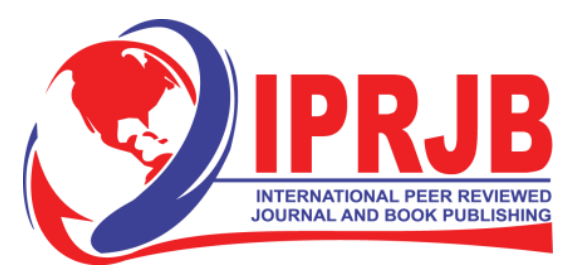

Www.iprjb.org

The correlation output further shows that there is a positive and significant correlation between money supply and growth of mortgage financing $(\mathrm{r}=0.594$, $\mathrm{p}$ value $=0.0002)$. This finding means that when the amount of money in circulation increases mortgage financing on the other hand also increases. Similarly, Karoki (2013) applied a descriptive research approach to reveal what controls prices of the real estate sector in Kenya and found that supply of money had an influence on prices of real estate which was positive and significant.

\subsection{Regression Analysis}

\section{Effect of Interest Rates on Growth of Mortgage Financing}

To examine how interest rates affect the growth of mortgage financing among Kenyan commercial banks a simple time-series regression analysis was conducted.

Table 3: R-squared and ANOVA

\begin{tabular}{|c|c|c|c|c|c|}
\hline Source | & SS & df & MS & Number of obs & 35 \\
\hline & & & & $\Gamma / 1$ & 8.69 \\
\hline & .97 & 1 & 0702 & Prob $>F$ & $=0.0377$ \\
\hline Resi & 6.85 & 33 & .2 & R-squared & $=0.1244$ \\
\hline Tote & 7.87367172 & 34 & 23157858 & $\begin{array}{l}\text { Adj R-squared } \\
\text { Root MSE }\end{array}$ & $\begin{array}{l}=0.0978 \\
=.45708\end{array}$ \\
\hline
\end{tabular}

The NOVA output shows that the probability $F$ test value was 0.0377 an implication that the variable is statically significant at a $95 \%$ confidence level. This means that the interest rate has significant explanatory power on the growth of mortgage financing. R squared is the coefficient of determination. The results indicate that the interest rate has 0.1244 or nearly $12.44 \%$ power in explaining the growth of mortgage financing as illustrated by the coefficient of determination (R$\mathrm{sq})$. The results demonstrate the model's fitness as a good estimator of the effect of interest rates on the growth of mortgage financing among Kenyan commercial banks.

\section{Table 4: Coefficients}

\begin{tabular}{rrrrrr} 
GMF | Coef. & Std. Err. & t & P $>|t|$ & {$[95 \%$ Conf. Interval] } \\
\hline IR | -.0324593 & .007055 & -4.60 & 0.038 & -.0629609 & -.0019576 \\
ccons | 5.078024 & .2809467 & 18.07 & 0.000 & 4.506433 & 5.649614
\end{tabular}

The $\mathrm{p}$-value for the t-test is 0.038 which is less than 0.05 meaning that the interest rate has a significant effect on the growth of mortgage financing among Kenyan commercial banks at a $95 \%$ confidence level. The coefficient of interest rate is -0.032 and the coefficient of the constant is 5.078. This shows that when the interest rate is 0 growth of mortgage financing is 5.078. The coefficient of interest rate is a negative coefficient meaning that the relationship is negative.

\section{Effect of Money Supply on the Growth of Mortgage Financing}


International Journal of Finance and Accounting

ISSN 2513-4311X (online)

Vol.6 Issue 2, No.1. pp. 1 - 11, 2021

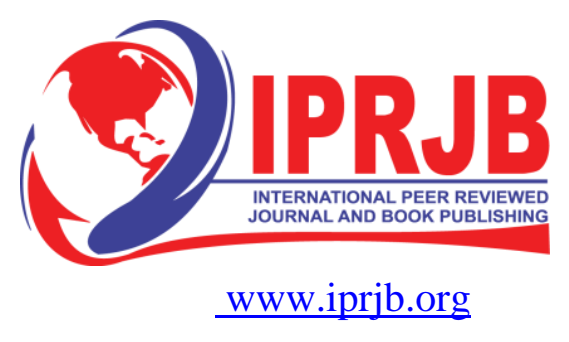

\section{Table 5: R-squared and ANOVA}

\begin{tabular}{r|rrr} 
Source & SS & df & MS \\
\hline Model & 2.77836972 & 1 & 2.77836972 \\
Residual & 5.095302 & 33 & .154403091 \\
\hline Total & 7.87367172 & 34 & .23157858
\end{tabular}

$\begin{array}{lrr}\text { Number of obs } & & 35 \\ \text { F ( 1, 33) } & 17.99 \\ \text { Prob }>\text { F } & 0.0002 \\ \text { R-squared } & =0.3529 \\ \text { Adj R-squared } & =0.3333 \\ \text { Root MSE } & =.39294\end{array}$

The NOVA output shows that the probability $F$ test value was 0.000 an implication that the variable is statically significant at a $95 \%$ confidence level. The variable has explanatory power. $\mathrm{R}$ squared is the coefficient of determination. The results indicate that the money supply has 0.3529 or nearly $35.3 \%$ power in explaining the growth of mortgage financing as illustrated by the coefficient of determination (R-sq). The results demonstrate the model's fitness as a good estimator of the effect of money supply on the growth of mortgage financing among Kenyan commercial banks.

Table 6: Regression Coefficients

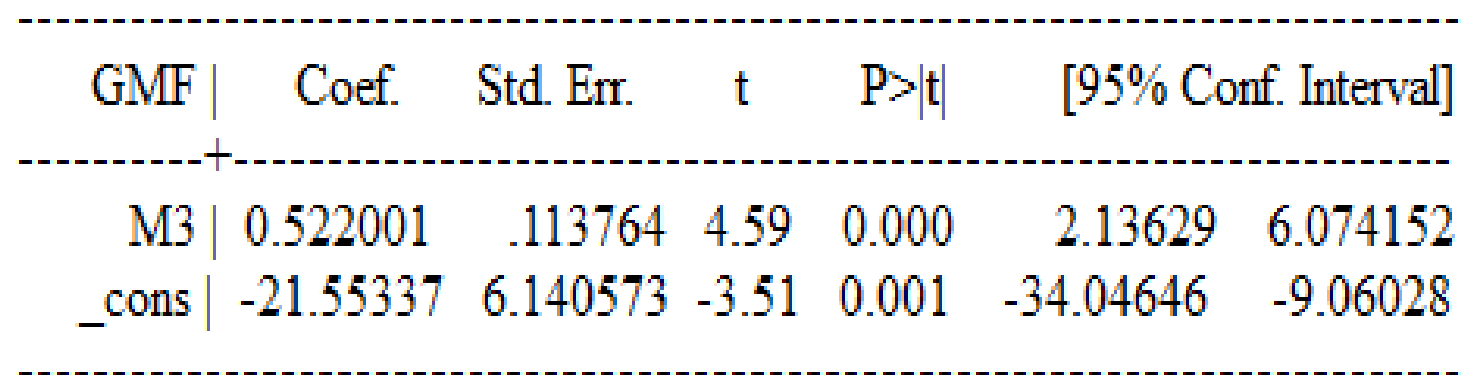

The $\mathrm{p}$-value for the t-test is 0.000 which is less than 0.05 meaning that money supply has a significant effect on the growth of mortgage financing among Kenyan commercial banks at a $95 \%$ confidence level. The coefficient of the money supply is 0.522 and the coefficient of the constant is -21.55 . This shows that when the money supply is 0 growth of mortgage financing is -21.55. The coefficient of the money supply is a positive coefficient meaning that the relationship is positive.

\section{Combined regression}

\section{Table 7: R-squared, ANOVA and Regression Coefficients}

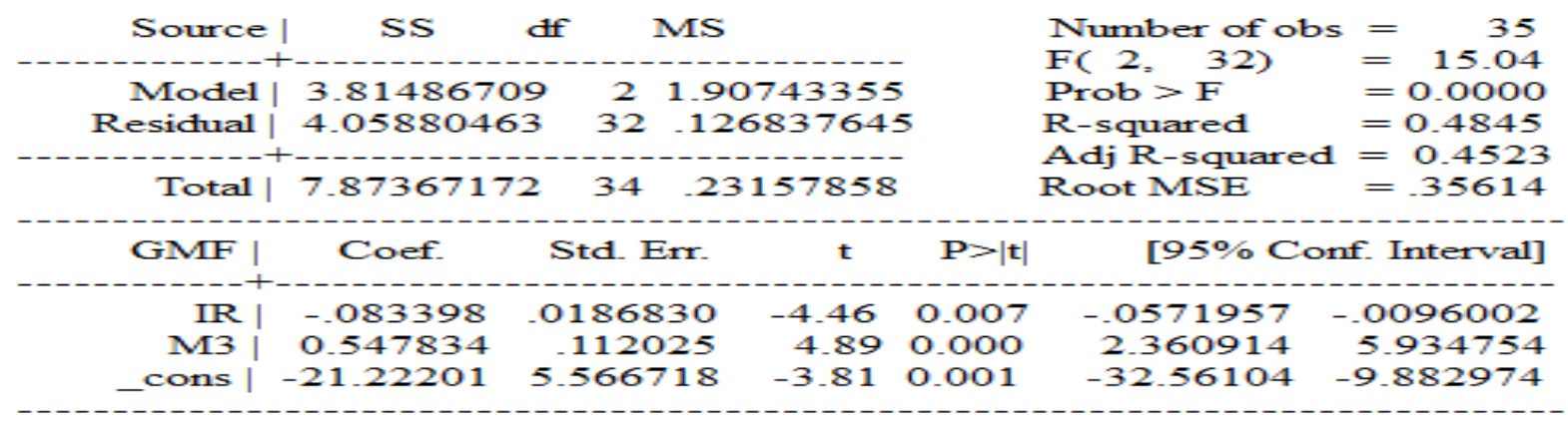


Interest rate and money supply had a combined explanatory power of 0.4845 or $48.45 \%$ on growth of mortgage financing as illustrated by the obtained $\mathrm{R}$ squared value. The output further shows that the analysis of variance (ANOVA) findings imply that the regression model is significant at 0.05 significance level as illustrated by the probability of the F statistics which is 0.0000. This further demonstrates that the model fits is a good estimator of the effect of the macroeconomic factors on the growth of mortgage financing among commercial banks in Kenya.

\section{$\mathrm{H}_{01}$ : Interest rate has no significant effect on the growth of mortgage financing among Kenyan commercial banks}

The regression output shows that the beta coefficient of interest rate is a significant predictor of the growth in mortgage financing as shown by the p-value of the $t$ statistics of 0.007 . It is also observed that the interest rate has a negative beta coefficient which is -0.0833 which means that the interest rate has a negative effect on the growth of mortgage financing. The null hypothesis that interest rate has no significant effect on the growth of mortgage financing among Kenyan commercial banks is rejected. The findings of the study are supported by Green and Wachter (2017) revealed that the decline in nominal prime interest rates from an average of 15 percent in 1980 to 4.4 percent in 2004 across several countries lead to improved access to mortgages, increase in demand for housing, and increase in house prices across most of the industrialized countries in the world.

\section{$\mathrm{H}_{02}$ : Money supply has no significant effect on the growth of mortgage financing among Kenyan commercial banks}

The beta coefficient of money supply (0.548) is positive and significant (p-value 0.000). A unit change in the money supply would change the growth of mortgage financing positively by 0.548 units. Therefore the null hypothesis that money supply has no significant effect on the growth of the mortgage financing among Kenyan commercial banks is rejected and concludes that money supply has a significant effect on the growth of the mortgage financing among Kenyan commercial banks. The findings of the study were consistent with that Karoki (2013) who found that supply of money had an influence on prices of real estate which was positive and significant.

\subsection{CONCLUSION AND RECOMMENDATIONS}

\subsection{Conclusion}

The study concludes that interest rate has a significant negative relationship with the growth of mortgage financing among Kenyan commercial banks. The study rejects the null hypothesis that interest rate has no significant effect on the growth of mortgage financing among Kenyan commercial banks thus interest rate has a significant effect on the growth of mortgage financing among Kenyan commercial banks.

The study concludes that there is a positive and significant correlation between money supply and growth of mortgage financing. The study rejects the null hypothesis that money supply has no significant effect on the growth of the mortgage financing among Kenyan commercial banks thus money supply has a significant effect on the growth of the mortgage financing among Kenyan commercial banks. 
International Journal of Finance and Accounting

ISSN 2513-4311X (online)

Vol.6 Issue 2, No.1. pp. 1 - 11, 2021

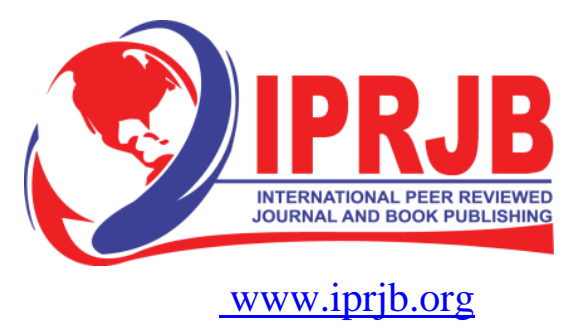

\subsection{Recommendations}

The Central Bank of Kenya should use monetary policies to ensure a steady supply of money in the economy to increase mortgage uptake. The government should intervene to manage interest rates and keep them at appropriate levels. This is due to the enormous impact they have on mortgage uptake; they set lending rates and, as a result, stimulate demand by increasing or decreasing access to credit. This is because the mortgage concept is sadly best suited for persons who can guarantee that they will be employed for a long time and/or have a steady source of income for a long time.

To attract mortgage takers, policymakers should ensure that the interest rates paid on mortgage facilities are competitive in the market. Since interest rates and money supply were identified as important factors in the mortgage business by the study, the government should establish legislation to protect the interests of both consumers and lenders in the market.

\subsection{Suggestions for further studies}

The study focused on only the commercial banks in Kenya; however other financial institutions offer mortgage loans. Thus further studies should consider incorporating the other financial institutions that offer mortgage loans. The study used interest rates and money supply variables and as such further studies could use other variables not included in the study. In addition, the study adopted specific measures of the study variables and thus suggests that other measures could be used by future researchers to ascertain the findings of the study.

\section{REFERENCES}

Agao, E. (2014). The effect of macroeconomic variables on the mortgage uptake for the mortgage industry in Kenya (Doctoral dissertation, University of Nairobi).

Ampofo, J. A. (2020). The nature of mortgage repayment plans in Ghana. Finance \& Accounting Research Journal, 2(3), 91-104.

Beck, M., Bryman, A., \& Liao, T. (2016). The sage encyclopedia of social science research methods. Sage Publications.

Brueggeman, W., \& Fisher, J. (2018). Real Estate Finance and Investments. Irwin: Mc-Graw Hill.

Central Bank of Kenya (2018). Bank Surveillance Report. Pg. 21-23

Central Bank of Kenya. (2017). Banking Supervision Annual Report. Nairobi: Central Bank.

Crowley, J. (2017). Interest Rate Spreads in English-Speaking Africa. IMF Working Paper. P123-45.

Drummond, I. M. (2013). British Economic Policy and Empire, 1919-1939. Routledge.

Green, K., \& Wachter, S. (2017). "The American Mortgage in Historical and International Context." Journal of Economic Perspectives, 19(4): 93-114.

Hass Consult Survey. (2013). Kenyan Property Market. Nairobi: Hass Consult.

Jumbale, D., K. (2016). The Relationship between House Prices and Real Estate Financing in Kenya (Doctoral dissertation, University of Nairobi). 
Karoki, R. W. (2013). Determinants of residential real estate prices in Kenya (Doctoral dissertation, University of Nairobi).

Kaufman, G. G., \& Erdevig, E. (2019). Improving Housing Finance in an Inflationary Environment: Alternative Residential Mortgage Instruments. In Housing and the New Financial Markets (pp. 359-371). Routledge.

Leonard, G. M. \& Owiti, K. (2013). The Determinants of Mortgage Uptake in Kenya using Capital Market indicators (Doctoral dissertation, Jomo Kenyatta University of Agriculture and Technology).

Muguchia, L. (2017). Effect of flexible interest rates on the growth of mortgage financing in Kenya (Doctoral dissertation, University of Nairobi).

Muli, N. F. (2016). An assessment of the factors affecting the growth in real estate investment in Kenya. Unpublished MBA Thesis. The University of Nairobi.

Ngacha, S. W. (2013). The effect of interest rate volatility on mortgage default rate in Kenya (Doctoral dissertation, University of Nairobi).

Olweny. T. (2011). Modeling Volatility of Short-term Interest Rates in Kenya. International Journal of Business and Social Science, Vol. 2 No. 7; Special Issue -April 2011.

Polit, D. F., Beck, T., \& Owen, S. V. (2016). Focus on Research Methods Is the CVI an acceptable Indicator of Content Validity? Appraisal and Recommendations. Research in Nursing \& Health, 30(6), 459-467.

World Bank report. (2016). Housing Finance Policy in Emerging Market. ISBN: 978-082137750-5. 